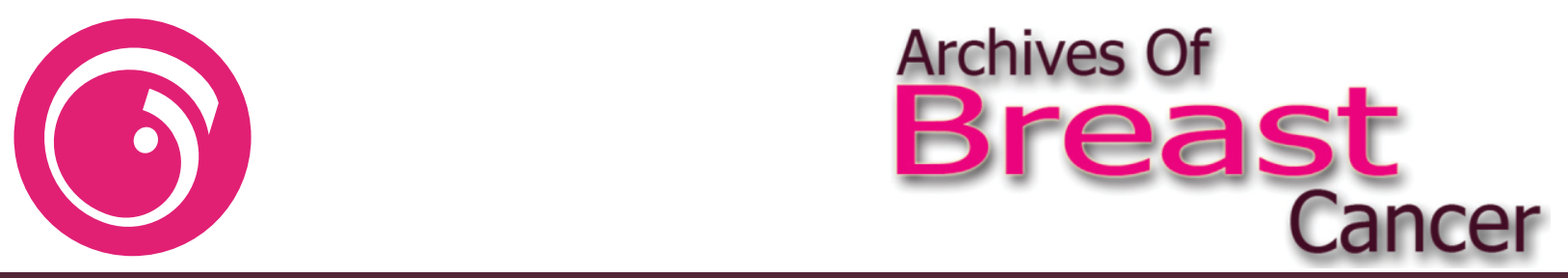

DOI: 10.32768/abc.20196249-50

\title{
Withholding Bad News: The Kiss of Death
}

\author{
Mohammad Reza Sasani ${ }^{* a}$ \\ ${ }^{a}$ Department of Radiology, Shiraz University of Medical Sciences (SUMS), Shiraz, Iran
}

In medical practice, delivering bad news to patients is a complicated issue. Clinicians sometimes are faced with the dilemma of delivering bad news to a patient: to tell or not to tell the truth. In this context, the religion of patients is an important factor. Some people, such as Muslims, believe in life after death and Judgment Day. Accordingly, avoiding disclosure of the pertinent information to such patients is a clear violation of patients' rights because it denies them the opportunity to do penance and seek God's forgiveness for their sins. This situation is an instance of "the kiss of death."

I read with interest the Invited Commentary by Tahmasebi ${ }^{1}$, entitled "Delivering Bad News: Deal With Collusion for Love," which was recently published in this journal. I would like to draw attention to the issue of breaking bad news to patients from a religious perspective.

Today, generally, avoiding the disclosure of the pertinent information to a patient is not ethically acceptable. ${ }^{2,3}$ On the other hand, in medical practice, giving bad news to patients is a complicated issue and a difficult task., 5 Clinicians are sometimes faced with the dilemma of delivering bad news to a patient, i.e., to tell or not to tell the truth. In this way, the patient's family may ask the doctor not to reveal such information as cancer diagnosis to their patient for one reason or another. Furthermore, patients' religion is one of the concepts that exert an influence on their care process and consideration of bad news. ${ }^{7}$ Some people, such as Muslims, believe in life after death and Judgment Day as well as the existence of Hell and Heaven. They believe that after death, sinners will go to Hell and good people will go to Heaven, and that God will accept the sinners'

\footnotetext{
* Address for correspondence: Mohammad Reza Sasani, MD

Assistant Professor,

Address: Medical Imaging Research Center, Nemazee Hospital, Zand Street, Shiraz, Iran.

Tel: +989177391618

Fax: +987136474329

Email:sasanimrz@gmail.com
}

repentance and, with true penitence, they will go to Heaven. Now imagine that a patient with such a religion and beliefs has terminal cancer, and the clinician does not provide information about prognosis to the patient per her family's request or for some other reason. This would be a clear violation of the patient's rights because it denies her the opportunity to do penance and pray for God's forgiveness. This situation is an instance of "the kiss of death." Hence, patients' religion is an important factor in breaking bad news. Therefore, doctors must tell the truth and disclose pertinent facts to such patients (of course, in supportive ways) and allow them to make changes to the remnants of their lives and eventually to their destiny.

\section{Conflict of Intrest}

None.

\section{References}

1. Tahmasebi M. Delivering bad news: deal with collusion for love. Archives of Breast Cancer. 2018:96-7.

2. Aljubran AH. The attitude towards disclosure of bad news to cancer patients in Saudi Arabia. Annals of Saudi medicine. 2010;30(2):141.

3. Buckman RA. Breaking bad news: the SPIKES strategy. Community oncology. 2005;2(2):13842.

4. Girgis A, Sanson-Fisher RW. Breaking bad news: consensus guidelines for medical practitioners. Journal of Clinical Oncology. 1995;13(9):2449-56.

5. Salem A, Salem A-F. Breaking bad news: current prospective and practical guideline for Muslim countries. Journal of Cancer Education. 2013;28(4):790-4.

6. Halligan P. Caring for patients of Islamic denomination: critical care nurses' experiences in Saudi Arabia. Journal of clinical nursing. 2006;15(12):1565-73.

7. Schoefl R. Breaking bad news. Digestive Diseases. 2008;26(1):56-8. 
Delivering bad news

8. McKennis AT. Caring for the Islamic patient. AORN journal. 1999;69(6):1185-96. 